Karadeniz Uluslararası Bilimsel Dergi

Volume: 50, Summer-2021, p. (333-357)

ISSN: 1308-6200 DOI Number: https://doi.org/10.17498/kdeniz.947480

Research Article

Received: May 3, 2021 | Accepted: June 6, 2021

This article was checked by turnitin.

\title{
POPULATION OF THE OCCUPIED TERRITORY OF SAMACHABLO IN THE MIDDLE AGES
}

\section{НАСЕЛЕНИЕ ОККУПИРОВАННОЙ ТЕРРИТОРИИ САМАЧАБЛО В СРЕДНЕВЕКОВЬЕ}

\section{İŞGAL EDILLEN SAMACABLO'NUN ORTAÇAĞDAKİ NÜFUSU ÜZERINNE}

Giorgi SOSIASHVILI ${ }^{*}$

\begin{abstract}
The significant part of Shida Kartli - Georgia`s historical region has been occupied since the Russo-Georgian August War of 2008. The territory, which was inhabited by the Georgian population from the ancient times and was an integral part of the Georgian area, was turned into South Ossetian Republic by the efforts of the so-called Ossetian separatists and Russian support. The current occupied territories of Didi Liakhvi Gorge were part of Samachablo in the Middle Ages. Samachablo was the feudal land of the representatives of one of the ancient Georgian noble family - the Machabeli. The present work shows the life of Georgians throughout centuries in Samachablo. Traces of population in the Big Liakhvi Gorge can be seen from ancient times, however, there is a lack of statistical data on the exact number of population until the XVIII century.

Thus, a comparative analysis of the census ledgers and other documentary material reveal that both, in Tskhinvali and in the villages of the Big Liakhvi Gorge, where the peasants of the Georgian royal family, various noble families and, for the most part, the Machabel feudal house lived, were predominantly Georgians. The Ossetians settled from the North Caucasus in the XVII-XVIII centuries lived only in the mountainous area of Shida Kartli (including the upper part of the Big Liakhvi Gorge). was facilitated by the royal government and various feudal houses (including the Machabels) in order to re-assimilate the deserted villages and increase the number of taxpayers. The migration of the Ossetians living in the mountainous villages to the lowland villages started more on that later.

Thus, based on the analysis of the presented documents, we can conclude that the territory of Samachablo, which is forcefully separated from the Georgian area, throughout centuries was inhabited only by Georgians (together with them fragmentarily lived Armenians and Jews, and later, particularly from the XVII century Ossetians, who came from the North Caucasus settled in the mountainous villages of Samachablo). After the August War of
\end{abstract}

\footnotetext{
* ORCID:0000-0002-2406-8662,Sosiashvili, G., Prof. Dr. Gori State Teaching University,
} Gori, Georgia, giorgisosiashvili@gmail.com 


\section{Population Of The Occupied Territory Of Samachablo In The Middle Ages}

2008, the inhabitants of Didi Liakhvi Gorge, Georgians, have become refugees in their own homeland.

Keywords: Samachablo, Georgians, Ossetians, Didi Liakhvi Gorge, Occupation.

\section{АННОТАЦИЯ}

Значительная часть Шида Картли - исторический регион Грузии - оккупирована после русско-грузинской войны 2008 года. Территория, которая с древних времен была заселена грузинским населением и являлась неотъемлемой частью территории Грузии, была превращена в Южно-Осетинскую республику усилиями так называемых осетинских сепаратистов при поддержке России. Нынешние оккупированные территории ущелья Диди Лиахви в средние века входили в состав Самачабло. Самачабло было феодальной землей представителей одного из древнегрузинских дворянских родов - Мачабели. Настоящая работа показывает жизнь грузин на протяжении веков в Самачабло. Следы населения в ущелье Большой Лиахви можно увидеть с древних времен, однако отсутствуют статистические данные о точной численности населения до XVIII века.

Сравнительный анализ переписных листов и других документальных материалов показывает, что как в Цхинвали, так и в селах ущелья большого Лиахви, где проживали крестьяне грузинской царской семьи, различные дворянские семьи, из них, в основном, феодальный дом Мачабели. преимущественно были грузины. В XVII-XVIII веках осетины с Северного Кавказа жили только в горной части Шида Картли (в верхней части ущелья большого Лиахви). Королевское правительство и различные феодалы (в том числе Мачабели) способствовали повторной ассимиляции заброшенных деревень и с целю увеличения количества налогоплательщиков. Позднее началось переселение осетин из высокогорных сел в низинные.

Таким образом, на основании анализа представленных документов можно сделать вывод, что территория Самачабло, насильственно отделенная от грузинской территории, на протяжении веков была заселена только грузинами (вместе с ними фрагментарно проживали армяне и евреи, а позже, в частности, с XVII века пришедшие с Северного Кавказа осетины селились в горных селениях Самачабло). После августовской войны 2008 года жители ущелья Диди Лиахви, грузины, стали беженцами на своей родине.

Ключевые слова: Самачабло, грузины, осетины, ущелье Диди Лиахви, оккупация.

\section{ÖZ}

Gürcülerin tarihi bölgesi bölgelerinden biri olan Şida Kartli'nin önemli bir kısmı 2008 RusGürcü savaşından sonra işgal edildi. Eski çağlardan beri Gürcü nüfusunun yaşadığı ve Gürcistan topraklarının ayrılmaz bir parçası olan bölge, Rusya'nın desteğiyle Osetin ayrılıkçılarının çabalarıyla Güney Osetya Cumhuriyeti'ne dönüştürüldü. Didi Liakhvi vadisinin işgal altında olan bölgeleri, Orta Çağ'da Samaçablo'nun bir parçasını oluşturuyorlardı. Samaçablo, eski Gürcü soylu ailelerinden biri olan Maçabelilere aitti. Bu çalışma, Gürcüler'in Samaçablo'da yüzyıllar boyunca yaşadıklarını göstermektedir. Büyük Liakhvi vadisindeki nüfusun izlerini eski zamanlardan beri görmekteyiz. Ancak 18. yüzyıla kadar kesin nüfus hakkında herhangi bir istatistik veriler mevcut değildir.

Nüfüs sayım defterlerinin ve diğer belgesel materyallerin karşılaştırmalı analizi hem Tskhinvali'de, hem de Gürcü kraliyet ailesine ait köylüler ile soylu ailelerin (Maçabeliler dahil) bulunduğu Büyük Liakhvi vadisi sakinlerinin çoğunun Gürcü olduğunu göstermektedir. 17. ve 18. yüzyıllarda, Kuzey Kafkasya'dan gelen Osetinler sadece Şida Kartli'nin dağlık kesiminde (büyük Liakhvi geçidinin üst kısmında) oturuyorlardı. Kraliyet 
hükümeti ve çeşitli soylu aileler (Maçabeliler dahil), vergi mükelleflerinin sayısını artırmak amacıyla terk edilmiş köylerin yeniden asimilasyonunu teşvik ettiler. Daha sonra Osetinlerin yüksek dağ köylerinden alt köylere yeniden yerleştirilmesi başlatıldı.

Bu nedenle, sunulan belgelerin analizi Samaçablo'nun Gürcülere ait topraklar olduğunu ve burada Gürcülerin yüzyıllar boyunca oturduklarını kanıtlamaktadır (Gürcülerle birlikte, bölgede Ermeniler ve Yahudilerin de bazı yerlerde oturdukları bilinir. Daha sonra, 17. yüzyıldan itibaren Kuzey Kafkasya'dan gelen Osetinler, Samaçablo'nun dağ köylerine yerleştiler). Ağustos 2008 savaşından sonra Didi Liakhvi vadisi sakinleri olan Gürcüler kendi anavatanlarında mülteci oldular.

Anahtar kelimeler: Samachablo, Gürcüler, Osetliler, Didi Liakhvi geçidi, işgal.

\section{Introduction}

The significant part of Shida Kartli - Georgia`s historical region has been occupied since the Russo-Georgian August War of 2008. The territory, which was inhabited by the Georgian population from the ancient times and was an integral part of the Georgian area, was turned into South Ossetian Republic by the efforts of the so-called Ossetian separatists and Russian support. The current occupied territories of Didi Liakhvi Gorge were part of Samachablo in the Middle Ages. Samachablo was the feudal land of the representatives of one of the ancient Georgian noble family - the Machabeli. The present work shows the life of Georgians throughout centuries in Samachablo.Traces of population in the Big Liakhvi Gorge can be seen (tsot'niashvili, 1956: 7-25) from ancient times, however, there is a lack of statistical data on the exact number of population until the XVIII century.

\section{Research methods}

In the given article we have used not only empirical, but purely theoretical methodologies, such as: generalization, analysis, synthesis, abstraction, comparison, systematic approach. Comparative-historical method and causality analysis has been used during the research process, which on its behalf unites the mentioned theoretical methodologies.

\section{Discussion}

The first more or less perfect document about the population of Samachablo is 'Great Ledger of Tbilisi Vilayet of 1728' (jikia, shengelia, 2009) which was created by the Ottoman government's (Sultan Ahmed III (1703-1730) order and its purpose was to census of the tax-paying population. The document gives us a certain idea about the economic situation of Samachablo, the social scales, the number of the population of this or that villages and settlements. The fiscal document includes the number of tax-paying persons and households. It is known that the conquered population was imposed a number of taxes by the Ottomans: Ushri (the tax for vineyards, cattle, bees and etc. They also had an income from the mills (depending on how many grindstones the mills had), custom -house, ferries...In the Ottoman ledger the type of tax (Isfenji-the tax for a farmland, Ushri-the tax for vineyards, Donumi-the tax for 40 steps land, 


\section{Population Of The Occupied Territory Of Samachablo In The Middle Ages}

Deshtibani-the tax for the cattle,bees etc), quantity (barley, rye, wheat, millet, hay, melted butter, beehive) and etc. are indicated along each village. All the villages are not presented in the Turkish document of 1728. Some of them are missed. There are some villages on the list of the Big Liakhvi which identification is difficult.The names of these villages were probably misapplied by the compilers of the book.E.g. there are the following villages in the documents: Zarseti, Kutakhlisi, Zinhkhlisi, Bardizi.(jikia, shengelia, 2009: 364-366) Each of these village is mentioned together with the other villages of the Big Liakhvi gorge. However, their localization and exact names cannot be determined. It is also possible that all the villages of the above -mentioned vague names were small and then they became the sites of deserted villages or joined the neighboring ones and became the part of them. According to 'Great Ledger of Tbilisi Vilayet', 205 men (families) with 116 households lived in Tskhinvali at that time,36 men (Head of the family) $^{* *}$, a family (ie a household)-22, in the village of Rustavi-18 men , household 11, in Monastery-19 families, 29 households, In Dammpaleti-18 families, households 13, in Tsari (this must be the village of Dzari which is mentioned by Prince Ioane of Georgia (Batonishvili) together with the villages which were included(bat'onishvili, 1986: 41) in the Big Liakhvi Gorge) there were 29 men, 14 households, in Tmarasheni-70 men, 42 households, in Kekhvi- 24 men, 11 households, in Achabeti-15 men, 8 households, in Kurta-18 men, 10 households , in Sveri- 19 men, 8 households, in Kemerti- 22 households, 43 men, in Zarseti $^{*}$ - 14 men, 5 households, in Kutakhlisi-7 men, 3 households, in Zinkhlisi- 4 men, In Chalisubani settlement -4 men, 5 households, in Sbatsminda8 men, 5 households, in Bardizi- 3 men, 2 households, in Kheiti- 4 men, 2 households. (jikia, shengelia, 2009: 351-366)The village of " Kutakhlisi" into the Amilakhvaris' submission is named in the Ottoman document where it is indicated

** In the XVIII century ledgers the term "head" was used which was considered the head of the family in the household by the Academician Iv. Javakhishvili. In his opinion, there might be some families in one household and there was "the head" in each family. (javakhishvili, 1901: 10-11) In our opinion, "the man'" mentioned in the ledger, is identical to ''the head', See. (sosiashvili, 2014: 49)

* the settlement with the similar name in the Big Liakhvi Gorge is not known, ,Zarseti" is mentioned neither in the ledgers of the second half of the XVIII century nor in the beginning of the XIX century ledgers conducted by the Russian government. According to the sequence of the geographical destinations presented in the Turkish document, it is possible to think that ,Zarseti", was the same Dzartsemi. As it is already mentioned, several villages with similar obscure names appear in the Turkish ledger: 'Kutakhlisi, 'Bardizi', "Zinkhlisi"'. The settlement of " Chalis ubani" is also censused there, which, in our opinion, might have been the settlement of "Chalis Ubani" Here there must be a note: in the Georgian language there is a difference between the letters of fand $\mathrm{h}$. That's why it's impossible to translate the author's opinion as both of the letters are translated as "ch"' in the English Language. The toponym "chala" was spread in the Liakhvi Gorge. As I. Megrelidze indicates, 'Chalis ubani "' was located on the right bank of the Big Liakhvi, nearby Kemerti. There is the church of Archangel where the representatives of the Machabelis were burried. (megrelidze, 1984: 71-72) 


\section{Giorgi SOSIASHVILI}

that: 'Teimuraz the son of Zurab is a prince, Vakhtang the brother of his, Iase the brother of his, Bezhan the son of Bachua is a nobleman, Simon the brother of his'.(jikia, shengelia, 2009: 364) In our opinion, the name of the village is misapplied in the ledger. However, the prince Teimuraz,-the son of Zurab may be Teimuraz Machabeli who fought against the Ottomans. Presumably, during compiling of the ledger, he had not been migrated from Samachablo. Due to the Ledger, Teimuraz Machabeli had two brothers: Vakhtang and Iase. It is possible that this last one is exactly that Machabeli who had been sent to Circassia for several times by Erekle II for moving the auxiliary detachment. (sosiashvili, 2018a: 116-119). Vakhtang Machabeli's political activity which is mentioned in the document, is unknown. As for the nobleman Bezhan the son of Bachua and his brother Simon, mentioned in the Ottoman document, they might have been the noblemen of the Machabelis. Allowedly, the village of Sabatsminda is censused in the Ottoman ledger, which is not mentioned separately in the Georgian ledgers of the II half of the XVIII centuries. The inhabitants of Kheiti and Sabatsminda are censused together in the ledger of the II half of the XVIII century. Kheiti and Sabatsminda are also mentioned together in Erekle II's document about the army on duty. As it seems, Sabatsminda joined Kheiti(lortkipanidze, 1947: 296) due to its few population. 'Great Ledger of Tbilisi Vilayet of 1728' has not survived to the present day and a number of village census papers have been lost. The document omits such settlements as: Dgvrisi, Kusireti, Kempheri and etc.

Only three churches are mentioned in the Big Liakhvi Gorge due to the census conducted by the Ottoman officials. We suppose St Virgin's church in the village of Tiri is implied in the village of "Monastery". (andghuladze, 1970: 204)

One church is also mentioned in the village of Tbeti. To our mind, this is Bortsvisjvari church of Tbeti (topuria, 1924: 134) and according to the Turkish document, the third church was in Tskhinvali. However, it is difficult to say which church is implied as there were a lot of churches in Tskhinvali at that time, among them were: Assumption of Virgin Mary, Holy Virgin's church, Kavti's church, Ascencion, Lomisi churches and etc.(megrelidze, 1984: 165-167; tsot'niashvili, 1986: 384-395)

It is difficult to elucidate the ethnic status of the population living in the villages of the Big Liakhvi Gorge exactly according to the 'Great Ledger of Tbilisi Vilayet of 1728" as only the names of the heads (men's) of the families united in the hoseholds and their fathers' names are fixed in the Ottoman document. Nevertheless, it must be noted that thera are basically the Georgian proper names in the document, such as: George, Sekhnia, Erekle, Beri and etc. In other villages (e.g. Tamarasheni, Chalis ubani) the Armenian proper names are fixed as well, e.g. Ohane, Sarkisa. (jikia, shengelia, 2009: 359, 365) There are Jewish ones in Tskhinvali and Tamarasheni, e.g. Mordekh-in Tskhinvali, Moshiain Tamarasheni. (jikia, shengelia, 2009: 358, 363). 


\section{Population Of The Occupied Territory Of Samachablo In The Middle Ages}

The mention of the Armenian and Jewish proper names in the Ottoman document is not accidental. It is known that from ancient times in Tskhinvali, Jews and Armenians lived together with Georgians.(vakhusht'i, 1973: 370) ${ }^{* *}$

The ledger compiled in the II half of the XVIII century of Tskhinvali and its neighboring villages preserved very interesting information about the population of the Big Liakhvi Gorge.

According to this document, the expanded surnames in the Big Liakhvi Gorge were the following ones: In Rustavi: Gadzabulidze, Basilidze, Kefari (It is written: K. Akav Kefari Patarkatsi Ninia and Beri) (tabuashvili, 2013: 70), in Monastery (in the same Monastery of Tiri): Epeniashvili, Darchiashvili, Chulikhadze, Berduladze, Zoziashvili. (tabuashvili, 2013: 62) In Tskhinvali: Unadze, Garsevanishvili, Muradashvili, Shedanashvili, Tseradze, Maisuradze, Chitiashvili, Masiashvili, Lomkatsishvili, Eliashvili, Gamchenashvili, Ohanashvili, Khanuashvili, Seirishvili, Gharibashvili, Chagelishvili, Khojashvili, Iaralashvili, Lalashvili, Gabrielashvili, Shadadgulashvili, Markozashvili, Mamistvalashvili, Israilashvili, Gakhelidze, Kvanchakhadze, Kevlashvili, Bakuzanashvili, Kanduashvili, Didebeli, Dalakishvili, Kakuashvili, Chamovardnashvili, Kasradze, Champuridze, Berishvili, Svimonashvili, Eranashvili, Miselashvili, Zazashvili, Nabichvrishvili, Javakhishvili, Khukhashvili, Makhniashvili, Enakolopashvili, Berunashvili, Zhamierashvili, Amiraghashvili, Kharshiladze, Kulijan Terpetrozashvili, Beglashvili, Dotashvili, Merabashvili, Janinashvili,Rusinashvili, Satuashvili, Ter Arakelashvili, Ter Arutenashvili, Kichikashvili,Goginashvili, Mamijanashvili, Khitarishvili, Alkhazishvili, Davitashvili,Kolelishvili, Bochoradze, Khanjalashvili, Eghishakashvili, Eliashvili, Papismedashvili, Khundiashvili, Salmakhanashvili, Kavadze, Bliadze, Atenelashvili, Karakhanashvili, Golinashvili, Aslanashvili, Teghbazashvili, Ghambarashvili, Amilashvili, Gongladze, Papakerashvili, Arutinashvili, Mosesashvili, Giorgishvili, Rostevanishvili, Metsiskvilishvili(tabuashvili, 2013: 54-60), Tsabadze, Maranashvili, Meurmishvili, Brodzveli, Metskhvarishvili. In Achabeti: Babutsidze, Khabareli. In Tamarasheni: Beghelashvili*, Khomasuridze, Elbakidze, Nadirashvili, Mindorashvili, Bortishvili, Otiashvili, Kakhishvili, Revazishvili**, Meladze, Apshikashvili, Gorelashvili(tabuashvili, 2013: 67).In Kurta: Maisuradze, Baadurishvili***, Khetsinashvili, Kereselidze, Alkhazishvili, Basishvili, Meladze, Khabareli, Akhalkatsi. (tabuashvili, 2013: 68) In Sveri: Giunashvili, Gebuadze, Meladze, Khetagashvili, Jirkvalishvili, Khetereli, Papelishvili, Lekutishvili.(tabuashvili, 2013: 68-69) In Kemerti: Metreveli, Kaulashvili, Gherkenashvili, Kasradze, Otinashvili, Maghaldadze,

** The Jewish people lived in the villages of the Big Liakhvi Gorge as well. See. (berdzenishvili, 2014: 179-180)

* one of the ramifications of the Machabelis, see. (sosiashvili, 2005: 47)

** the ramifications of the Machabelis, see. (sosiashvili, 2005: 47)

*** as it seems from the document,the mentioned surname was one of the ramifications of the Machabeli. 
Mkervalishvili(tabuashvili, 2013: 69-70). In Kheiti: ${ }^{* * * *}$ Mikeladze, Khidasheli, Dalaksishvili, Romelashvili, Ugrekhelashvili, Dokvadze, Bugianishvili, Machaidze, Sabanadze, Gamrekelashvili, Begashvili, Kekelishvili, Nikolishvili, Khimshiashvili, Gochashvili, Gochunishvili, Pekhshishvelashvili, Chumashvili, Sherazadishvili, Kulichishvili, Mamisashvili, Kurdghelashvili, Zubashvili and etc. (tabuashvili, 2013: 70-72)

Most of the villages of the Big Liakhvi Gorge which are mentioned in Great Ledger of Tbilisi Vilayet of 1728 are also in the II half of the XVIII century Georgian Ledgers, but by the end of the century some of them do not appear there, e.g. Dampaleti and Tbeti.It is possible that during compiling of the II half of the XVIII century, these villages had already been deserted and because of this the officialregistrerssent by the Kartl-Kakheti royal court did not include them in the ledgers.

The comparison of Great Ledger of Tbilisi Vilayet with the ledgers of the 80 s of the XVIII century Tskhinvali and its neighboring villages give us a good opportunity to make a conclusion about the dynamics of the population of the Big Liakhvi Gorge during 40-50 years. 113 households, 168 Heads (tabuashvili, 2013: 54-60) are censured in Tskhinvali according to the document dated 1781 (i.g. the population of Tskhinvali increased by 9 households in half a century); In Sveri there were 15 households and 24 familis (Sveri population is increased by 7 households)(tabuashvili, 2013: 68-69); In Kemerti-16 households and 34 families (Kemerti population is reduced by 6 households)(tabuashvili, 2013: 69-70); In Achabeti- 6 households and 10 families (Achabeti population is reduced by 9 households)(tabuashvili, 2013: 62-63);In Rustavi-3 households and 7 families (Rustavi population is reduced by 16 households)(tabuashvili, 2013: 70); In Kekhvi-9 households and 20 families (Kekhvi population is reduced by 30 households and 51 families)(tabuashvili, 2013: 61-62). In Kheiti-30 households and 51 families (Kheiti population is increased by 26 households)(tabuashvili, 2013: 70-72). During 50 years, in 4 of the 6 enumerated villages (Kemerti, Achabeti, Rustavi, Kekhvi) the population decreased by 47 households, while in three of them (Tskhinvali, Sveri and Kheiti) it increased by 42 households. It is conceivable that in these three settlements we have to deal with the internal migration of the population. Otherwise, the population would have grown in other neighboring villages as well.

It is interesting that the number of other nationalities (Georgians, Armenians, etc.) in the 1781 ledger, is expressed by the households and by family members, the Jews indicated only by the housholds number, e.i." in the town of Rtskhinvali -a Jew Abrama Eliashvili fromAkhaldaba, Moshia and Daniela the household...A ...K. Akav.a refugee Jew Elia Atanelashvili and Moshia the household, the prince (Batonishvili) Iulon's peasant serf' (tabuashvili, 2013: 60) and etc. What might be the reason for this?Possibly, this was due to the fact that the

${ }^{* * * *}$ supposedly, the populations of Kheiti and Sabatsminda are censused together in the document. 


\section{Population Of The Occupied Territory Of Samachablo In The Middle Ages}

ledger compiled by the government's order had two purposes: tax and military. As the Jews had only tax liabilities, only their household indexes were included in the ledger.

Through the Observation on the document it is clear that there was an active movement of the population, e.g. censused in Tskhinvali are: those released from captivity, refugees, those who belonged to this or that monastery (Christ's tomb, Mtatsminda's, Kvatakhevi's, St Virgin's, John the Baptist's , Echmiadzin's ) and the inhabitants of various villages (Akhaldaba, Tamarasheni, Prisi, Bekami, Brodza, Ali and etc) settled in Tskhinvali as well.

The ledgers of the "duty army" compiled during Erekle II's reigning, clearly represent the population of Samachablo and its ethnical composition in the 70s of the XVIII century. (lortkipanidze, 1947)

The ethnic picture of the Big Liakhvi Gorge is clearly seen in the "'duty army" ledgers. From December 1774 until March 1775, Tazia, Svimona and Katsia Sherazadishvilis, Mamuka Gamrekelashvili, Kitesa Khidasheli, Bezhan and Beri Romelashvilis, Beri Beridze, Katsia and Tevdore Khimshiashvilis, Gogia Sosiashvili, Topchi Berika, Javakh Gogia (lortkipanidze, 1947: 296-298)and etc. from the villages of Kheiti and Sabatsminda, had to be on duty on the army.

Erekle's army included Tseradze Kitesa (the Queen's stableman), Makhniashvili Gogia, Koberidze Gogia, Maisuradze Khosro, Aslanishvili Berua,Goginashvili Mikela, Merabishvili Meraba, Palbukhashvili Papa,-a peasant serf of Echmiadzin, Elizbara,-the son of Karapeta from Ateni, Asaturashvili Mosia, Geurkashvili Mandzula, Mamajanashvili Revaza, Shaburishvili Kitesa, Koberidze Gogia, Kvalianidze Ninia, Masiashvili Ivane, Ossetian Dakhchikoshvili Tiko, Gogia,-a peasant serf of Machabeli,Tilisa Osmana and others (in total 38 men) from Tskhinvali.

The list of Tskhinvali for the "duty army" included local peasants as well as the 'Queen's.' They were: Kakhniashvili Bezhan from Kekhvi, Baatashvili Berua from Dirbi, Lashakhishvili Baadur from Ateni, Mghebrishvili Goderdza from Surami, Davitashvili,-the peasant serf of David, Mamukashvili Beri (lortkipanidze, 1947: 344-345) from Meskheti and others.

There were $6 \mathrm{men}$ in total in the "duty army" from Dgvrisi : Meshvlidishvili Gogia, a new peasant serf Vardzielashvili, -a male relative of the monk, Abiatar's Datua who lived in Racha and then moved to Imereti, Abiatar's Pavlenishvili's monk's peasant serf Nonia, Noniashvili Gabriel, Gotsiridze Glakha.(lortkipanidze, 1947: 345)

From Tamarsheni: (6 men in total), Avtandil Belashvili's peasant serf Giua, a private peasant serf Metreveli Khosikashvili zaralo, a private peasant serf monk Gagnidze, Iese Machabeli's peasant serf Ninia Metreveli, Ioseb, the bastard of Machabeli, Machabeli Otiashvili Revaz.

From Kurta: Baadur's son Zaza, monk Khutsinashvili, Kereselidze Datuki, Chulukhadze Sekhnia,- a peasant serf of Tiri monastery, Kandelakishvili Katsia,Iese Machabeli's peasant serf. 


\section{Giorgi SOSIASHVILI}

From Sveri: Mose Salamadze and Berika Jirkvelashvili.(lortkipanidze, 1947: 346)

From Kemerti: Metreveli Kikola, Tevdore and Gogia, Iese Machabeli's peasant serfs: kasradze Nikoloz and Paata.

From Dzartsemi: Gogia Machabeli's peasant serf monk Kopadzishvili, a private peasant serf Gogidze tamaza, the priest Basil Elbakidze, a private serf Buchua,-the cousin of Ivane Khutsishvili,Jojiashvili Revaz,-the Aragvi Domain (Sabatonishvilo), (5 men in total).

In addition, Iase Machabeli was instructed to bring out peasant serfs from Ergneti, Dzartsemi,Kemerti,Tamarasheni in December(lortkipanidze, 1947: 344346). Kheiti in December. Revaz Machabeli (lortkipanidze, 1947: 304)was in charge of bringing out peasant serfs from the village of Kheiti in March, Iase and Zaza Machabeli (lortkipanidze, 1947: 305) had to bring out peasant serfs from the same village in April, In May-Iase and Revaz Machabeli (lortkipanidze, 1947: 305)and etc.

One more statistic document about Shida Kartli population dated 5 April, 1770 is a demographic list, according to which the Machabelis owned in the Big Liakhvi Gorge:' eight hundred and sixty (households) Ossetians, forty Jews' '(gamrek'eli, tskit'ishvili, 1973: 153). The most part of the population on the territory of our interest presented by the local Georgian peasants, which is confirmed with the entry in the above mentioned document: „Except the Christian Orthodox Georgian refugees, Kartli belongs to the serfs of the churches and four thousand nobles"'. (gamrek'eli, tskit'ishvili, 1973: 153)

According to G.Togoshvili's opinion, around 6000 (togoshvili, 1969: 165) hoisehold of Ossetians had lived on the territory of Georgia by 1770. However, this researcher does not specify which statistical information or documents he cites this data. . This figure is exaggerated, as the analysis of the documentary material below also confirms it.

The census conducted by prince Ioane of Georgia (Batonishvili) contains important information about various gorges, villages or the deserted villages, the ethnical composition of the population and the properties of the nobles of KartlKakheti in the last decade of the XVIII century which he had implemented by the instruction of Erekle IIand George XII and it reflects the situation of 17941799.(bat'onishvili, 1986)

Although, names and surnames are not indicated in the ledger, but it is clarified whether the village is inhabited or deserted by the population and who owns it. E.g. In the middle of the Big Liakhvi Gorge "in the villages of the Samachablo Gorge, the following is listed: Krtskhinvali, the town of Pichkhi, Zghuderi, Dgvrisi, Ghelis Ubani, Tamarasheni, Achabeti, Abotsminda, Dampaleti, Kurta, Kekhvi, Kekhvi, Zemtkhvisi, Dzartsemi, Kemerti, Sveri.Among them "resident" is indicated everywhere. it is only specified that "Ossetians live" in Gupta from the listed villages. 'Zatsevi"' and 'Kheiti" (bat'onishvili, 1986: 41) is censused without any inhabitants. Kheiti had been inhabited by that time (Obviously, by the Georgians) and as it seems prince Ioane of Georgia 


\section{Population Of The Occupied Territory Of Samachablo In The Middle Ages}

(Batonishvili) overlooked it. As for the upper part of the Big Liakhvi Gorge, it is indicated in the ledger that 'Ossetians live there". Certainly, the Ossetian settlers in the mountainous part of Samachablo are implied there. Accordin to Ioane of Georgia's (Batonishvili's) census, the following villages at the upper part of the Big Liakhvi Gorge are inhabited: Khoso, Small Java, Skhlebi, Khvtse, Muguti, Kimasi, Koshka. Keshelta is mentioned as a deserted village.

According to the same census: the Gorges of Roka, Sba, Zakha and Nara belonged to the royal court.(bat'onishvili, 1986: 41-42)

In the census of prince Ioane of Georgia's (Batonishvili's) we can find the data about the meadows, mountains, mineral deposits in the royal property, episcopal centers, pastures and hunting places, extinct and toponyms of that time.(bat'onishvili, 1986: 13)

On the basis of the above-presented ledgers and other statistic documents, it seems that the Georgians were the native inhabitants in Tskhinvali and its neighboring villages by the second half of the XVIII century. The Armenians and Jews lived together with the Georgians. The Ossetians coming down from the North Caucasus ( it is also fragmented) were only in the villages located on the upper part of the Big Liakhvi Gorge, who occupied the territories abandoned by the Georgians.

Prince Vakhushti (Batonishvili) wrote about it: "And how many Ossetians we censused in these places, for the first time Georgian peasants settled there. Later, the Ossetians were settled by their owners and the Georgians settled on the plain place because the privious inhabitants there had been reduced by the enemies." (vakhusht'i, 1973: 363-364).

The issue about the Ossetians' settlement was studied by a number of scientists.(apkhazava, 1991; totadze, 1996; gamqrelidze, 1996; gvasalia, 1983; lomouri, 1992; itonishvili, 1992; Гамрекели, 1961; Абаев, 1949; Ванеев, 1936; Пфаф, 1870; Волкова, 1974 and etc.) Prof. R. Topchishvili dedicated a long monograph to the migration of the Ossetians, that is why and we are not going to speak about this issue extensively. According to the researcher, as a result of the Ossetians migration to the Shida Kartli highlands, a number of Georgian surnames converted to the Ossetian ones. E.G. the Gergaulis inhabited in the village of Tontobeti in the Big Liakhvi Gorge, being the Dvalis by the origin, were influenced by Ossetians and became the Gergaloves. (topchishvili, 1997: 29)

The Dvalis' migration to the South and the Ossetians inhabitance on their private lands, basically started from the XVI century, though this process was not once-only. E.g. in one of the documents dated 1636, Chantadze and Tegadze are mentioned as the inhabitants of Dvaleti. Later, they migrated to Kartli and Kakheti. (topchishvili, 1997: 40)

The author of the XIV century historical source " History of the Eristavs", uses the terms 'the black Dvalni"' and 'the lower Dvalni" (meskhia, 1954: 348, 357)for indicating of the Dvalis' who migrated from Dvaleti to the mountainous villages (Koshka, Zghuberi, Roka, Tlia, Bekhushe and etc.) of the Big Liakhvi Gorge. 


\section{Giorgi SOSIASHVILI}

The settlement of Ossetians from the Caucasus in the upper reaches of the Big Liakhvi was mainly from the Alagiri gorge, however, in these areas by the II half of the XVI century a significant part of the population was still Georgian. E.g. the Garakanisdzes (topchishvili, 1997: 100) are mentioned at that time, among the inhabitants of Java. The inhabitants of the XVIII Java also were: the Sisvelauris, the Gagasdzes,the Butkhuzis.(topchishvili, 1997: 156-157) The Dvalishvilis, the Gergaulis, the Bagauris and others (topchishvili, 1997: 166) lived in the highlands of the Big Liakhvi Gorge.

The Ossetians migrated to the highlands of Shida Kartli in the second half of the XVIII century, tried to settle in Tskhinvali but it was difficult for them. It is confirmed with the document dated 1782 due to which a former Ossetian Ivane migrated to Tskhinvali, sold himself to Davita PoraksashviliAdamashvili.(sosiashvili, 2018b: 181-182) If the Ossetians had lived in Tskhinvali and its neighboring, in the villages of the Big Liakhvi Gorge, the ledgers would have fixed them definitely. The Ossetians migrated to the highlands of Shida Kartli in the II half of the XVIII century called the ancient Georgian town of Tskinvali with the Ossetian name. According to the German traveller Johann Anton Gueldenstaedt's ${ }^{\square}$ information, the Ossetians called (gelashvili, 1962: 279) Tskhinvali Kreba. ${ }^{*}$ During the census of the Tskhinvali population, it is fixed in the Great Ledger of Tbilisi Vilayet of: " the Ossetian peasant serf, the son of Babuna". (jikia, shengelia, 2009: 358) It is interesting that the "Head' of the families males' proper names living in Tskhinvali: Basila-the son of Babuna, Datuna,-the son of Kogi, Iorgi (supposedly it may be George-G.S.), Mamuka,-the son of Kohkadra are followed by "'an Ossetan peasant serf, the son of Babuna."

In our opinion, "the Ossetian peasant serf "' was converted to the proper name from the term expressing the social condition of the migrated Ossetians to Georgia. The surname Osikmashvili was exactly originated from it . "The Ossetian peasant serf' which became his proper name, is found in the document dated 1566. "The Ossetian peasant serf" ("'Osikma'), living in Bedikara - one household, was donated by King Leon to the monastery of David Gareji.(bakradze, rat'iani, otkhmezuri, 2004: 343)

The Osikmashvilis must have been Georgianized Ossetians. This surname is found in some documents of the II half of the XVII century.(bakradze, rat'iani, otkhmezuri, 2004: 343)' Osikmashvili', is also found with its different form in the Georgian onomastic. In one of the documents of the I half of the XVI century includes 'Osikmasashvili', and in the document dated 1699, it is found as ''Osikmesashvili', .(bakradze, rat'iani, otkhmezuri, 2004: 343)

After the conquering of Kartl-Kakheti Kingdom and its unification with Russia (1801), At the administrative point, the eastern Georgia was divided into five regions: Tbilisi-Lore, Gori and Dusheti (in Kartli), Telavi and Sighnaghi (in Kakheti).

*Guldenstaedt made a small inaccuracy, the Ossetians called Tskhinvali not Kreba but Chreba 


\section{Population Of The Occupied Territory Of Samachablo In The Middle Ages}

From the above, Gori region was the biggist one in terms of its population number and the area. Its territory was 5280 verst (Обозрения Российских владении за Кавказом, 1836) and it also included Samachablo. Districts (Округ) were established in Tbilisi and Gori regions in 1842-43. Three territorial units were established in Gori Region: Java, the Small Liakhvi and the Ksani.(Зиссерман, 1870: 48) The North part of the Gori region, from Java to the Roki-Erman terning was called the Ossetia district (Осетинскийучасток) in 1865. (Чхетия, 1954: 781)

As soon as the Russian government was established, the agenda was to collect information about the population of Georgia: in terms of demographics, fiscal and military. (antadze, 1973: 27)

Iantsov,-the district police chief started to census the Gori region by the command of Viceroy Paul Tsitsianov on April 2, 1803 and finished on July 4, 1804. Although, he could not manage to census the rgion completely, as the officials were not allowed to enter the villages where the inhabitants were Ossetians ( $i n$ the villages of the Big and Small LiakhviGorge, also the mountainous villages of the upper part of the Ksani Gorge, where the most part of the inhabitants were the Ossetians) and as Tsitisanov pointed out in his report, he was wounded himself during the battle. (goris ist'oriul-etnograpiuli muzeumi (gsiem), 7486: 3)The census conducted by the Russian government referred to only the tax-paying population.Unlike men, only the number of females was listed, even without their first and last names. The census did not refer to the privileged ranks and the citizens from the foreign countries.

The census had been over by 1805 and on the basis of the collected statistic material.In 1806, a general agency was set up on the number of the tax-paying people for the treasury expedition, according to which (the census did not include Mtiuleti, Tusheti, Pshav-Khevsureti)a total of 153.6 thousand taxpayers were registered in the censused regions of Eastern Georgia and 33.4 thousand in Gori region.(s.e.a.s.ts.a. p. 254, s. \#58, p. 1-78.)

The census covers 189 villages existing in different gorges of Gori region at that time, including the villages of the Big Liakhvi Gorge.

According to the census of the villages of Gori region in 1804 Iase, Zaza, Revaz, Luarsab, Parsadan, Bardzim, Datua and Avtandil Machabelis had peasant serfs in 31 villages and in Tskhinvali. In total, the Machabelis owned 261 households peasant serfs. Among them were 12 Jew households, 17 Armenian households and 20 Ossetian households. The Machabelis owned 1632 peasant serfs out indicated 261 households, of which 948 were males and 684 females.(gsiem, 7486: 5-136)

The Machabelis owned the peasant serfs: in Kekhvi, Sveri, Kurta, Kemerti, Kheiti, Sabatsminda and etc. Due to the census of 1804, the Machabelis' peasant serfs are represented as follows: in Tskhinvali 17 Armenian households (48 men, 39 women) and 6 georgian households (23 men, 18 women) were belonged to the Machabelis. 
In Sunisi* Iase Machabeli had 1 household ( 3 men, 1 woman. ${ }^{* *}$

The same Iase Machabeli had 1 household (3 men, 3 women) in Avlevi.

Revaz Machabeli had 3 households (11men, 6 women) in Meghvrekisi.

Luarsab Machabeli-1 household (6 men, 2 women). Skuneti.

Revaz Machabeli had 2 Ossetian households (10 men, 3 women) in

Bardzim Machabeli had 7 households (19 men, 12 women) in Kurta.

Zaza Machabeli-5 households (13 men, 8 women).

Datua Machabeli-8 households (18 men, 15 women).

Iase Machabeli-1 household (1 man, 1 woman).

Zaza Machabeli had 6 households (20 men, 10 women) in Kekhvi.

Iase and Revaz Machabeli had 9 Ossetian households (32 men, 24 women) in Dzartsemi.

Zaza Machabeli -1 household (4 men, 2 women) at Tiri Monastery.

Luarsab Machabeli had 6 households (20 men, 16 women) in Sveri.

Iase Machabeli - 1 household ( 5 men, 4 women).

Here, 4 households (14 men, 12 women) were in the common possession of the Machabelis.

9 households (39 men, 24 women) were in the common possession of the Machabelis.Among them, Teimuraz Machabeli possessed 2 households (10 men, 4 women).

Mikhael Machabeli-2 households (6 men, 3 women).

Hector Machabeli-5 households ( 23 men, 17 women).

1 Ossetian household (4 men, 1 woman) was in the common possession of the Machabelis in Kheiti.

Iase Machabeli had 4 households (14 men, 18 women);

Revaz and Iase Machabelis-34 households (118 men, 72 women);

Bardzim Machabeli -4 households (15 men, 13 women).

Revaz and Iase Machabelis-6 households ( 28 men, 20 women).

25 households (62 men, 41 women) were in the common possession of the Machabelis in Tamarasheni.

Avtandil Machabeli owned 9 households ( 27 men, 16 women).

Jews -12 households (57 men, 46 women).

14 households (52 men, 31 women) were in the common possession of the Matchabelis in Dgvrisi.

The nobles in the Machabelis' possession-2 households (6 men, 3 women).

Datua Machabeli-1 household (16 men, 7 women).

\footnotetext{
* the village in Karli municipality (Tighvi community). It was included in Znauri district until 1991.It is situated on the right bank of the river Middle Proni (the left tributary of the West Proni). At an altitude of $800 \mathrm{~m}$ above sea level, $1.5 \mathrm{~km}$ from Kornisi.

** In the list we indicate the nationality only to the non-Georgian population, where it is not explained, it is meant that there are Georgians everywhere.

*** A village of a similar name no longer exists today. Georgian historical sources cannot determine its exact location.
} 


\section{Population Of The Occupied Territory Of Samachablo In The Middle Ages}

Zaza Machabeli -1 household ( 2 men, 3 women).

Revaz Machabeli owned 1 household ( 2 men, 2 women) in Kvemo Nikozi.

Datua Machabeli owned 1 household (4 men, 3 women) in Zemo Nikozi.

6 households ( 2 men, 18 women) were in the common possession of the Machabelis in Zemo Khviti.

Iase Machabeli owned 1 household ( 2 men, 2 women).

1 household (6 men, 2 women) was in the common possession of the Machabelis in Kvemo Khviti.

Luarsab Machabeli possessed 5 households (18 men, 22 women) in Achabeti.

Zaza Machabeli had 1 household (6 men, 4 women) in the same village.(gsiem, 7486: 5-136)

As we see, the Machabelis had peasant serfs in the Big Liakhvi Gorge, in the Prone Gorge and on the right bank of the Matkvari as well in the beginning of the XIX century.

In 1804, out of 182 households censused in Tskhinvali, in terms of ethnic composition, the picture was as follows: 7 households of the fiscal nobles were Georgians, 8 households of the same category were Armenians; Fiscal peasants: 79 Armenian households, 6 Jews households, 7 Catholics households, 5 Ossetian households, 7 Georgian households; 6 Armenian, 2 Ossetian, 1 Georgian households were in the possession of the Kherkheulidzes' in Tskhinvali. 2 Georgian households belonged to the Orbelianis; In Abashidze's possession-1 Armenian and 2 Georgian households; In the possession of Holy Virgin's (supposedly, St Virgin's Cathedral built in 1718 in Tskhinvali) there were 6 Georgian households; The Machabelis owned 17 Armenian households, 6 Georgian households; The nobleman Arkadishvili owned 1 Armenian household; The Kherkheulidzes 6 Ossetian, 2 Armenian and 1 Georgian households; The Amilakhvaris-4 Georgian households; The Mukhranbatonis'-2 Georgian households; The Tsitsishvilis-1 Georgian household; The Tumanishvilis-2 Georgian households; The noble Davitashvilis-1 Georgian household. (gsiem, 7486: 34-35)

In 1804, there were 11 households living in the village of Sveri (all were Georgians, they were the property of the local princes - the Machabelis). In Kekhvi there were 20 households (all were Georgians, the Queen Darejan possessed 13 households, the Machabelis-7 households); 23 households lived in Kurta (all were Georgians, Bardzim Machabeli possessed 7 households, Zaza Machabeli-5, Datua Machabeli-8, Iase Machabeli-1and Taktakishvili-2 households)(alimbarashvili, 2021: 88-89).23 households (11 men and 76 women) are indicated in the census of Kemerti. Only 1 household is Ossetain( 4 men, 1 woman) among them. The rest of 22 households are Georgians. 7 households out of 23 belonged to Iase and Zaza Machabelis, 6 households are in the possession of St George's church of Kemerti, 
9 households belong to Tiri Monastery* in the possessions of the Machabelis and Revaz Eristavi (alimbarashvili, 2021: 89) owns 1 household. The Russian officials censused 11 households (all Georgians)(alimbarashvili, 2021: 91)who were in the Amilakhvaris' a nobleman Namoradze's possession in Tbeti. 42 households (all Georgians) were censused in Kheiti in 1804.

4 out of them belonged to Iase Machabeli, Revaz and Iase Machabelis owned 34, Bardzim Machabeli-4 households).(alimbarashvili, 2021: 90) 6 households (all Georgians)(alimbarashvili, 2021: 90) lived in Sabatsminda in the possession of Revaz and Iase Machabelis. 61 households are censused in the village of Tamarasheni: 34 Georgian households and 12 Jews households belonged to the Machabelis, the Qeen Darejan owned 7 Jews and 4 Georgian noble households.(alimbarashvili, 2021: 90) ${ }^{* *}$

It is obvious from the ledgers that the Lezghins and Ossetians attacked the Georgians frequently. They kidnapped: children, harvest, cattle and they destroyed everything what they could not take away.(gsiem, 7486: 10, 22, 45-46, $48,86,88,90,91,127,136$ and etc.)

The migration of the population from the North to the South is noticeable due to the Russian censuses. E.g. "the newly settled Ossetians", (Прибылихосетинцев)(gsiem, 7486: 8) is pointed out in the village of Prisi, and 8 households (30 persons) (gsiem, 7486: 10) are recorded in the number.

If we compare the data of Tskhinvali and its surrounding villages in the Great Ledger of Tbilisi Vilayet of 1728 with the Russian cameral census of 1804, we get the following picture: 36 families lived in the village of Tbeti in 1728 , but only 11 families are recorded in the same village in 1804 . The population in the village of Kekhvi was reduced by 4 families during 75 years (24 families is censused in Tbilis Vilayet Ledger, but according to the cameral census of 180420 families are censused). Sveri population consisted of 19 families in 1728, but in 1804 it was 11 . Kemerti populations was 22 in 1728 ,but according to the census of $1804-23$. During compiling of the ledger,Kurta population was 18 , but during the cameral census it was 23. 12 families were recorded by the Turkish census takers in Sabatsminda and Kheiti, but in 1804 - 2 (they included in Kheiti). Tamarasheni population consisted of 70 families in 1728, in 1804 it was 61 . Tskhinvali population consisted of 205 families in 1728, but in 1804- 182 .

The textbook "History of South Ossetia", approved by the Public Education Board of the South Ossetian Autonomous Region and published in 1990, states that "according to the 1804 census, there were 1,015 people (193

\footnotetext{
* „МонастыряТаодевифтисШобели, принадлежащегокнязьямМечабеловым” is indicated in the document, (gsiem, 7486: 91). It must be meant ' $S t$ Virgin of the Sinfuls' Cautioner',

** It must be noted that 2 peasant serf households of Tiri St Virgin's Cathedral who were in the Taktakishvilis' possession, are recorded in the village of Kurta due to the census, (alimbarashvili, 2021: 88). Supposedly, 1 peasant serf household belonged to St Virgin cathedral of Tiri that was recorded in the village of Tamarasheni. (alimbarashvili, 2021: 90)
} 


\section{Population Of The Occupied Territory Of Samachablo In The Middle Ages}

households) living in Tskhinvali, of which 44 (16 households) were Ossetians." (chibirovi, 1990: 60)According to the census of 1804, Ossetians are indeed registered in Tskhinvali, but instead of 16, there are 12 households. The 261 Georgians*** and 591 Armenians recorded in Tskhinvali during the census are not deliberately explained in the Ossetian textbook.(alimbarashvili, 2021: 55)

A census conducted by the Russian authorities in 1818 to determine the ethnicity and number of the population of Samachablo is relatively complete. It already contains extensive information about each family.

In total, the census covers the dates of 89 villages of Shida Kartli (former Gori region) and 1799 households (6394 men, 4338 women)(alimbarashvili, 2021: 37 , appendix graphic depiction $1-\mathrm{a} ; 1-\mathrm{b} ; 677-678)$ are censused. The reduction of the population is noticeable in some villages of the Big Liakhvi Gorge. E.g. 8 households (24 man, 13 women-all Georgians) are pointed out in Achabeti, but only 3 households (14 men, 8 women-all Georgians) in Achabeti. Achabeti population was reduced by 4 people and Kekhvi population was reduced by 59 people. As it seems, the inner migration processes took place at that time. Acording to the census of 1818 Paata Akhalkatsishvili,-a peasant serf of David Machabeli in Zemo Nikozi, together with his brother and family moved "from the village of Kurta and he did not appear in the old ledger"(gsiem, 8300: 143). Prince Bardzim Machabeli resettled 3 peasants in his possession from the village of Kemperi (gsiem, 8235: 135) in Meghvrekisi 4 years ago (i.e.1814). David Machabeli's peasant serf Ninia Basishvili immigrated from the village of Kurta(gsiem, 8300: 178) to Kelktseuli and etc.

By 1818, the population of Tskhinvali (both Georgian, Armenian, and Jewish) had not changed significantly. According to the census of 1818, 203 Georgians (121 men, 82 women), 135 Armenian (98 men, 37 women) and 192 Jews (125 men, 74 women), in total 730 people (344 men, 193 women)(alimbarashvili, 2021: 422-433)*lived in Tskhinvali. According to the population statistics, if we count an average of 5-6 people in a household, at that moment in Tskhinvali, about 37 households were Georgians, 24 households were Armenians and 36 households are Jews.

Migration processes were noticeable in the villages of the Big Liakhvi Gorge according to the census of 1818. The new sttlers (the Ossetians among them) pointed out from which villages and when they migrated, which makes it easier to determine the date of migration. If we summarize these data, $70 \%$ of the settlers come from the last 15 years. That is, after the establishment of Russian rule in eastern Georgia.

\footnotetext{
${ }^{* * *}$ In the above census, the Imeretians and Georgians are indicated in a separate column. *Tskhinvali population had noticeably increased by the end of the XIX century and there had been 516 households (in total 2913 people, among them 1610 were men and 1303 women) by 1885.720 Gerogians (398 men, 322 women), 641 Armenians (355 men, 286 women), 16 Ossetians ( 9 men, 7 women) lived in Tskhinvali at that time . Most residents were Jews- in total 1525 people $(848$ men, 677 men). (ТрудыТифлисскогогубернскогостатистическогокомитета, 1886: 87).
} 
It is notable that the term "The South Ossetia"' is not used by the census takers and we found the term "'Ossetia"' (gsiem, 8235: 48, 53, 55 and etc.) for the indication of the original habitat of the Ossetian population settled in Georgia, which means the territory of the Ossetians living in the North of Caucasus. The term "Ossetia" is used conventionally to denote the place of residence of Ossetians living in Georgia.

The mistakes existing in the previous ledgers are accurated in the census of 1818. In particular, about the ownership of excellent families, the number of peasants, ethnicity, etc. E.g. it is indicate in Tskhinvali that: " according to the older census 17 Armenian households who turned out Georgians,were pointed out''. (gsiem, 8300: 176) In some cases the peasants mentioned in the previous census are represented as owned by another owner during the new census.

E.g. it is indicated in Achabeti that:,,according to the old census, Luarsab Machabeli's 5 households peasant serfs are in the possession of Hector Machabeli" (gsiem, 8300: 30). In Ergneti: ,the peasants belonged to Elizbar Machabeli are in his son Michael Machabelis'(gsiem, 8235: 145) possession now" and etc.

The number and ethnic composition of the peasants in the Machabelis' possession in thevillages of the Big Liakhvi Gorge according to the census of 1818 , give such a picture:

In Meghvrekisi- Bardzim Machabeli owned 1 household (3 people, all Georgians)(gsiem, 8235: 135-136).

In Ergneti-Michael Machabeli owned 4 households ( 39 people, 30 men, 9 women, all Georgians).(gsiem, 8235: 155-158)

In Dgvrisi Michael Machabeli had 2 households ( 9 people, 6 men, 3 women, all Georgians).

In the same village, Hector Machabeli possessed 5 households (27 people, 14 men, 13 women, all Georgians).

In the same village, Bardzim Machabeli had 2 households (14 people, 7 men, 7 women, all Georgians).(gsiem, 8235: 126-158)

In Tskhinvali, Teimuraz and Luarsab Machabelis had 3 households (11 people, 7 men, 4 women, all Georgians).

In Tskhinvali Hector Machabeli had 5 households (25 people, 17 men, 8 women, among them 19 were Georgians and 6 Armenians).

In Tskhinvali Bardzim Machabeli had 10 households (48 people, 28 men, 20 women, all Georgians).

It is indicated in the same document that: "17 households belonged to the Prince Machabelis were included as Armenians but they turned out Georgians"'.(gsiem, 8300: 176)

In Achabeti, Bardzim and Zaza Bortishvili-Machabelis owned 2 households (10 people, 7 men, 3 women, all Georgians).

In the same village, Hector Machabeli possessed 5 households (6 people, 4 men, 2 women, all Georgians). 


\section{Population Of The Occupied Territory Of Samachablo In The Middle Ages}

In the same village, Teimuraz Bortishvili-Machabeli had 1 ( 9 people, 10 men, 3 women, all Georgians). (gsiem, 8300: 27-30)

In Kekhvi, Teimuraz Bortishvili-Machabeli owned 1 households of Zaza Machabeli's former serfs (9 people, 4 men, 5 women, all Georgians).

In the same village, Bardzim Bortishvili-Machabeli owned 2 households (13 people, 10men, 3 women, all Georgians).(gsiem, 8300: 32-33)

In Kurta Bardzim Bortishvili-Machabeli had 3 households (31 people, 17 men, 14 women, all Georgians).

In the same village, Teimuraz Bortishvili-Machabeli had 3 households (20 people, 10 men, 10 women, all Georgians).

In the same village, David Machabeli had 5 households (22 people, 15 men, 7 women, all Georgians).

In the same village, Hector Machabeli owned 1 household (4 people, 2 men, 2 women, all Georgians).

David Machabeli's servants lived in the same village as well (6 people, all Georgians).(gsiem, 8300: 36-42)

Hector Machabeli owned 11 households (52 people, 34 men, 18 women, all were Georgians) in Tamarasheni.

Hector and Ninia Machabelis had also servants in the same village (2 people, both were Georgians).

Bardzim the son of Revaz Machabeli had 6 households (38 people, 23 men, 15 women, all Georgians) in Tamarasheni. ${ }^{*}$

Teimuraz the son of Parsadan Machabeli owned 7 households,- 3 Jews households out of them, according to the number of people 17, 4 Georgian households-5 men and 8 women in Tamarasheni.

Michael Machabeli had 3 Jews households, 20 people in total, 14 men, 6 women in Tamarasheni.(gsiem, 8300: 56)

Revaz Machabeli owned 9 households (55 people, 33 men, 22 women, all Georgians) in the same village.

Bardzim Machabeli had 2 households, 1 was a Jews household out of them (7 men, 3 women) and 1 was a Georgian household (3 men, 1 woman).

Revaz and Iase Machabelis' former peasants fell to Hector Machabeli through the new census in Sabatsminda-2 households (18 people, 9 men, 9 women, all Georgians).

Teimuraz Machabeli owned 2 households (18 people, 13 men, all Georgians) in the same village.

Hector Machabeli owned 1 household (5 people, 4 men, 1 woman, all Georgians) in the same village.

Bardzim Machabeli owned 1 household (6 people, 4 men, 2 women, all Georgians) in the same village.

\footnotetext{
* it is indicated in the same document that: „Ivane Ialghuzidze and his brothers Zaza, Eprem and Solomon and their mother living together with Ivane-settled from Ossetia who were not censused in the old ledger and also 6 servants''. See: (gsiem, 8300: 52).
} 


\section{Giorgi SOSIASHVILI}

Revaz Machabeli owned 9 households (36 people, 30 men, 16 women, all Georgians) in the same village. (gsiem, 8300: 44-61)

Bardzim the son of Revaz Machabeli had 12 households (69 people, 43 men, 26 women, all Georgians) in the same village.

Bardzim Bortishvili-Machabeli owned 1 household (10 people, 5 men, 5 women, all Georgians) in the same village.

Michael Machabeli owned 1 household ( 9 people, 5 men, 4 women, all Georgians) in the same village.

Teimuraz Bortishvili-Machabeli possessed 1 household (4 people, 2 men, 2 women, all Georgians) in the same village.(gsiem, 8300: 67-70, 79-91)

Parsadan Machabeli had 10 households (60 people, 40 men, 20 women, all Georgians) in Kheiti.

Michael Machabeli had 3 households (15 people, 10 men, 5 women, all Georgians) in the same village. (gsiem, 8300: 70-79)

Teimuraz the son of Parsadan Machabeli had 1 household (6 people, 4 men, 2 women, all Georgians) in Dzartsemi.

Michael Machabeli had 3 households (27 people, 16 men, 11 women, all Georgians) in the same village.

Hector Machabeli had 6 households (39 people, 25 men, 14 women, all Georgians) in the same village.

Bardzim the son of Revaz Machabeli had 4 households (30people, 15 men, 15 women, all Georgians) in the same village.(gsiem, 8300: 97-100)

Teimuraz the son of Parsadan Machabeli had 2 households (14 people, 10men, 4 women, all Georgians) in Kemerti.

Michael Machabeli had 2 households ( 8 people, 5 men, 3 women, all Georgians) in the same village.

Hector Machabeli had 5 households (40 people, 21 men, 19 women, all Georgians) in the same village. (gsiem, 8300: 102-107)

Bardzim the son of Revaz Machabeli had 3 households (17 people, 11 men, 6 women, all Georgians) in Zemo Nikozi.

Michael Machabeli had 2 households (11 people, 7 men, 4 women, all Georgians) in the same village. (gsiem, 8300: 110-124)

Michael Machabeli had 1 household ( 8 people, 5 men, 3 women, all Georgians) in Kvemo Nikozi. (gsiem, 8300: 131)

Hector Machabeli had 1 household (4 people, 2 men, 2 women, all Georgians) in Zemo Khviti.

David Machabeli's peasant serf 1 household (4 people, 3 men, 1 woman, all Georgians) moved from the village of Kurta to Zemo Khviti.

Bardzim Bortishvili-Machabeli had 1 household (9 people, 6 men, 3 women, all Georgians) in the same village. (gsiem, 8300: 143-144)

David Machabeli had 1 household (5 people, 4 men,1 women, all Georgians) in Kvemo Khviti. (gsiem, 8300: 163)

Hector Machabeli had 1 household ( 9 people, 5 men, 4 women, all Georgians) in Dzlevijvari. 


\section{Population Of The Occupied Territory Of Samachablo In The Middle Ages}

David Machabeli had 3 households (14 people, 7 men, 7 women, all Georgians) in the same village.

Teimuraz Bortishvili-Machabeli had 1 household (6 people, 4 men, 2 women, all Georgians) in the same village. (gsiem, 8300: 165-167)

21 Households (66 men, 38 women ) are listed in Kelktseuli. 1 household out of 21 belonged to David Machabeli (2 men, 1 woman ) who he took from Kurta. (gsiem, 8300: 165-178)

Hector Machabeli had 1 household (5 people, 4 men, 1 woman, all Georgians) in Pkhvenisi.(gsiem, 8300: 195)

Givi and Andria Gozashvilis bought by Teimuraz Bortishvili-Machabeli in Ossetia lived in Shindisi.

Michael Machabeli had 1 household (3 people, 2 men, 1 woman, all Georgians) in the same village. (gsiem, 8300: 203-215)

Teimuraz and Simon Machabelis had 4 households (38 people, 25 men, 13 women, all Georgians) in Variani.

Michael Machabeli owned 1 household ( 8 people, 4 men, 4 women, all Georgians) in the same village.

Bardzim Machabeli had 1 household (15 people, 9 men, 6 women, all Georgians) in the same village.

Hector Machabeli had 1 household (3 people, 2 men,1 woman, all Georgians) in the same village.

Teimuraz Bortishvili-Machabeli had households (29 people, 15 men, 14 women, all Georgians) in the same village.

Baram Bortishvili-Machabeli had 7 households (44 people, 28 men, 16 women, all Georgians) in the same village.(gsiem, 8300: 218-232)

Teimuraz Machabeli had 2 households (16 people, 28 men, 16 women, all Georgians ) in Sveri. (gsiem, 8300: 251)

As it seems, the majority of Samachablo population is Georgian in the 20s of the XIX century.

According to the census, the Machabelis had owned 221 peasant serfs in 23 villages of Shida Kartli by 1818 which amounted to approximately 1204 souls. The ethnic picture did not change much later. Due to the German traveler Edward Aikhenvald's information, there had been about 200 houses by 1825 in Tskhinvali. Most of the population were Georgians. In addition, there were 30 Jewish families(aikhvaldi, 2005: 235). in Tskhinvali, as well as 3-5 Ossetian households."

In total, 2209 households ( 7703 people) had been censused by 1838 in the fiscal notification of Gori region, 1605 households (4825 people) were censused in the ecclesiastical notification and 4462 households (18695) were included in the bondhold notification. Among them 24581 were Georgians, 4593-Armenians, 1573-Ossetians, 504-Jews.(Зиссерман, 1870: 62-63). i.e. By the early 30s of the

\footnotetext{
* it is noteworthy that when referring to the number of Jews in Tskhinvali, Aikhenvald names 40 families in one place and 30 in another. See: (aikhvaldi, 2005: 231, 235).
} 
XIX century, $79 \%$ of the 31,223 population in Gori were Georgians, $15 \%$ Armenians, $0.5 \%$ Ossetians, and $0.2 \%$ Jews.

The ecclesiastical ledgers of the villages of Samachablo give us some idea about the number, ethnic and religious properties of the population of the Big Liakhvi Gorge in the 60s of the XIX century. In 1969, in the village of Kurta, I. Megrelidze was shown the ledger of 1860 of St George church, where 84 households are censused there. 41 households from Kekhvi, 8 households from Zemo Achabeti, 23- from Kvemo Achabeti, 2-from Monastery (Tiri Monastery) are included there.

Priest George the son of Gabriel Basishvili (41 years old) and his children (Michael, Sidonia, Evstati), George's brother Manase and his wife Melanie, a widow his sister in-law Tamari, deacon Ephrem the son of Gabriel Basishvili, his wife Gaiane, their daughter Daria, the second lieutenant, Prince Dimitri the son of David Machabelov (63 years old), his wife Nino the daughter of Aroni (52 years old), their son David (26 years old), the warrant officers: Prince Michael the son of Teimuraz (44 years old) and Zaal the son of Kaikhosro (33 years old) Machabelis are mentioned in the ledger.

The servants of the Machabelis and their peasant serfs are represented in the ledger: Besarion Khutsinashvili, Glakha the son of George Jioshvili. According to the document,At that time the representatives of the following families lived in the above mentioned villages (Kurta, Kekhvi, Zemo Achabeti, Kvemo Achabeti, Monastery): the Titirashvilis, the Tedeshvilis, the Kazhashvilis, the Jokhadzes, the Kochiashvilis, the Basishvilis, the Khachapuridzes, the Elbakidzes, the Khutsinashvilis, the Kasabashvilis, the Tskhovrebashvilis, the Maisuradzes, the Zangaladzes, the Kakhniashvilis, the Nebieridzes, the Bliadzes, the Melanashvilis, the Chulukhadzes, the Papelashvilis, the Gherkenashvilis, the Khosiashvilis, the Razmadzes, the Tvalashvilis, the Khabarelis, the Babutsidzes, the Otiashvilis. (megrelidze, 1969: 130).

The ledger of 1878 of St George church is Kurta is also important,where the number of the parish of this church is shown. According to the document, the parish of Kurta consisted of 78 households which accounted 606 people in number (352 men, 254 women).However, there was a mistake in the quantitative data of the ledger, the re-summary of which revealed that the parish of the St George of the village of Kurta numbered 694 people. Among them 390 were men and 304women. The priest was again George Basishvili. Unlike the previous document, Dimitri Machabeli is no longer mentioned (presumably, he had been already dead) in the ledger. Among the excellent ones is named David the son of Dimitri Machabeli is named among the nobles ones.

According to the data of April 11, 1865, 41 households lived in Kekhvi, 27 -in Kurta, 8 -in Zemo Achabeti, 23 -in Kvemo Achabeti, 2 -in Monastery.(megrelidze, 1969: 131)

The number of the Ossetians settled from the North of Caucasus in the villages of the middle and upper parts of the Big Liakhvi Gorge was increasing gradually. By the 60s of the XIX century, Ossetians had already been densely 


\section{Population Of The Occupied Territory Of Samachablo In The Middle Ages}

populated in the mountainous villages of the Big and Small Liakhvi Gorges: Dmenisi, Satikhari, Snekvi, Khaduriantkari, Geri, Java, and etc.(Зиссерман, 1870: 53-54)

In the second half of the XIX century, the Georgian population was gradually moving away from the villages in the upper part of the Big Liakhvi Gorge. The population of Sabatsminda had reduced by 2 households by (12 households in 1860 (Зиссерман, 1870: 156), 10 households in 1886(Труды Тифлисского губернского статистического комитета, 1886: 51), Sveri population reduced by 19 people (75 people in 1860 (Зиссерман, 1870: 156), 56in 1886 (Труды Тифлисского губернского статистического комитета, 1886: 33). Big and Small Dzartsemi population reduced by 113 people (251 in 1860 (Зиссерман, 1870: 156), 138 in 1886 (Труды Тифлисского губернского статистического комитета, 1886: 36)and etc. However, in the XIX century, in the villages mentioned above (as well as in Kemerti, Kurta, Kekhvi, Monastery, etc.) the majority of the population were Georgians, Ossetians lived in fragments along with them. (Свод статистических данных о населении Закавказского края ..., 1893: \#1297-1305, 1394)

The Ossetian population increased by 53600 people on the territory of Georgia in 1801 - 1897 and from 31,500 it achieved 85 000, 100. (antadze, 1973: 88) However, these data may be incomplete, as the cameral censuses were not conducted in the mountainous villages of the Liakhvi Gorges, where the Ossetians settled in Georgia lived.

If we take into account that the mountainous villages were small, it will not change much the official data of the Ossetians living in Georgia at that time. (antadze, 1973: 80)

By 1869, Ossetians in Tbilisi province had accounted for $7 \%$ of the total population. (Зиссерман, 1870: 208)

By the beginning of the 70s of the XIX century, the number of Ossetians in Georgia as a whole did not exceed $4.56 \%$, but their number was growing sharply compared to Georgians. E.g. the average growth rate of Georgians in 1801-1832 was $0.15 \%$, Ossetians $-0.27 \%$, and Jews - 0.24\% (antadze, 1973: 88) The same data in $1832-1864$ was $0.97 \%$ for Georgians, $1.09 \%$ for Ossetians and $0.99 \%$ for Jews. In the 10-year period 1886-1897, the growth rate of Georgians was $1.01 \%$, Ossetians - 1.14\%, and Jews - 1.58\%. (antadze, 1973: 88)

The internal migration of Ossetians settling in the Shida Kartli highlands (from the mountains to Bari) in 1873-1886 was especially strong.

In 1915, the population of Tskhinvali achieved 710 households (tsot'niashvili, 1986: 204) and in 1917 - the number of Tskhinvali residents increased to 900. Among them, there were 310 Georgian households, 346 Jews, 160 Armenians, 80 Ossetians and 4 Russians.(tsot'niashvili, 1986: 204-205)

Ossetians settling in the Shida Kartli highlands were moving further and further to the South. This process was sometimes facilitated by the government officials. E.g. in 1873 there were 123 villages in Gori region, 76 were Georgian, 23 Ossetian and 19 mixed type out of them. As it turns out, 186 Ossetian families 
were relocated from 12 Ossetian villages in the villages of Shida Kartli valley at that time. 1 family from Vanati, 19-from Geri, 17- from Kimasi, 11-from Kobi, 39from Ortevi, 5-from Maraleti, 34 households from Zghubiri and Sba were settled. (Мачабели, 1887: 160-145-157)3 households did not live in the 80s of the XIX century in the village of Barsi of the Big Liakhvi Gorge (Java region) out of 9 censused in 1871. Twohouseholds of the Gaishvilis migrated in the village of Tormaneuli in 1871 and one family of the Jioshvilis-in Gaghmamkhari. 11 households out of the censused 19 in the villages of Khvedureti and Borgvnisi (the Big Liakhvi Gorge, Roki rural Society) no longer lived on the site in 1871. They relocated to the different highland and valley villages at different times. (topchishvili, 1997: 183) According to the 1886 family lists, 8 out of 43 households registered in the village of Dodonista situated on the Keshelti bank, -a tributary of the Big Liakhvi, lived on the site. They displaced in 1871 and settled in the villages near Tskhinvali: Dampaleti, Dodoti, Tbeti, (topchishvili, 1997: 186) etc.

\section{Conclusion}

Thus, a comparative analysis of the census ledgers and other documentary material reveal that both, in Tskhinvali and in the villages of the Big Liakhvi Gorge, where the peasants of the Georgian royal family, various noble families and, for the most part, the Machabel feudal house lived, were predominantly Georgians. The Ossetians settled from the North Caucasus in the XVII-XVIII centuries lived only in the mountainous area of Shida Kartli (including the upper part of the Big Liakhvi Gorge). was facilitated by the royal government and various feudal houses (including the Machabels) in order to re-assimilate the deserted villages and increase the number of taxpayers. The migration of the Ossetians living in the mountainous villages to the lowland villages started more on that later. Thus, based on the analysis of the presented documents, we can conclude that the territory of Samachablo, which is forcefully separated from the Georgian area, throughout centuries was inhabited only by Georgians (together with them fragmentarily lived Armenians and Jews, and later, particularly from the XVII century Ossetians, who came from the North Caucasus settled in the mountainous villages of Samachablo). After the August War of 2008, the inhabitants of Didi Liakhvi Gorge, Georgians, have become refugees in their own homeland.

\section{REFERENCES}

aikhvaldi, e., (2005). eduard aikhvaldi sakartvelos shesakheb, germanulidan targmna gia gelashvilma, tbilisi.

alimbarashvili, i., (2021). shida kartlis (goris mazris) mosakhleoba XIX sauk'unis p'irvel otsts'leulshi rusuli k'ameraluri aghts'erebis mikhedvit, gori. andghuladze, n., (1970). tiris monast'ris ts'arts'erebi, ,,matsne”, \#5, tbilisi. antadze, k'., (1973). sakartvelos mosakhleoba XIX sauk'uneshi (ist'oriuldemograpiuli gamok'vleva), tbilisi.

apkhazava, n., (1991). alanebi da sakartvelo, tbilisi. 


\section{Population Of The Occupied Territory Of Samachablo In The Middle Ages}

bat'onishvili, i., (1986) kartl-k'akhetis aghts'era, t'ekst'i gamosatsemad moamzades, gamok'vleva da sadzieblebi daurtes t. enukidzem da g. bedoshvilma, tbilisi.

bakradze, a., rat'iani, 1., otkhmezuri, g., (2004). p'irta anot'irebuli leksik'oni, masalebi shek'ribes da gamosatsemad moamzades ana bakradzem, levan rat'ianma da giorgi otkhmezurma, t'. III, tbilisi.

berdzenishvili, n., (2014). ist'oriuli dok'ument'ebi sakartvelos ebraelta shesakheb, n. berdzenishvilis redaktsiit, s.s.i.p'. davit baazovis sakartvelos ebraelta muzeumi, shromebi, I-II-III, tbilisi.

gamrek'eli, v., tskit'ishvili, z., (1973). 1770 ts'lis 5 ap'rilis demograpiuli nuskha, „matsne" ist'oriis, arkeologiis, etnograpiisa da khelovnebis ist'oriis seria, \#1, tbilisi.

gamqrelidze, b., (1996). osebis gansakhlebis sak'itkhisatvis sakartveloshi, ts'ignshi: „osta sak'itkhi”, a. bakradzisa da o. chubinidzis red. gori-tbilisi.

gelashvili, g., (1962). giuldensht'edt'is mogzauroba sakartveloshi, germanuli t'ekst'i kartuli targmaniturt gamostsa da gamok'vleva daurto g. gelashvilma, t'. I, tbilisi.

gvasalia, j., (1983). aghmosavlet sakartvelos ist'oriuli geograpiis nark'vevebi (shida kartli), tbilisi.

goris ist'oriul-etnograpiuli muzeumi (gsiem), 7486.

gsiem 8235.

gsiem 8300.

gsiem, 7486.

vakhusht'i, (1973). aghts'era sameposa sakartvelosa, tbilisi.

tabuashvili, a., (2013). kalak tskhinvalis da misi mimdebare soplebis aghts'eris davtrebi, tbilisi.

togoshvili, g., (1969). sakartvelo-osetis urtiertoba XV-XVIII ss. tbilisi.

totadze, a. (1996). osebi kartul mits'a-ts'qalze, ts'ignshi: „osta sak'itkhi”, a. bakradzisa da o. chubinidzis red. gori-tbilisi.

topuria, v., (1924). shida kartlshi datsuli zogiert sidzveleta ts'arts'erebi, saist'orio moambe, II, tbilisi.

topchishvili, r., (1997). sakartveloshi osta chamosakhlebisa da shida kartlis etnoist'oriis sak'itkhebi, tbilisi.

itonishvili, v., (1992). aghmosavlet sakartvelos mtianetis ist'oriidan, tbilisi.

lomouri, n., (1992). osta sakartveloshi chamosakhlebis ist'oriis dziritadi asp'ekt'ebi, zhurn. ,tsisk'ari”, \#5, tbilisi.

lortkipanidze, i., (1947) sabutebi erek'le mepis morige jaris shesakheb, sakartvelos sakhelmts'ipo muzeumis moambe, $t^{\prime}$. XIV-B, tbilisi

megrelidze, i., (1969). liakhvis kheobis ts'arts'erebi da skhva sidzveleebi, sakartvelos metsnierebata ak'ademiis ,,matsne”, \#6, tbilisi.

megrelidze, i., (1984). sidzveleebi liakhvis kheobashi, t'. I, tbilisi.

meskhia, sh., (1954) dzegli eristavta (ksnis eristavta sagvareulo mat'iane), t'ekst'i gamostsa, gamok'vleva, leksik'oni da sadziebeli daurto shota meskhiam, masalebi sakartvelosa da k'avk'asiis ist'oriisatvis (msk'i), nak'v. 30, tbilisi.

s.e.a.s.ts.a. p. 254, s. \#58, p. 1-78. 
sosiashvili, g., (2005). samachablos ist'oria, tbilisi.

sosiashvili, g., (2014). akhalgori „1728 ts'lis tbilisis vilaietis didi davtris” mikhedvit, goris sakhelmts'ipo sasts'avlo universit'et'i, kartul-turkuli mult'idistsip'linaruli sametsniero k'onperentsia, k'onperentsiis masalebi, tbilisi.

sosiashvili, g., (2018a). machablebis urtiertoba chrdiloet k'avk'asiastan (cherkezebi, daghest'nelebi, osebi), ,kartuli dip'lomat'ia”, ts'elits'deuli, 18, tbilisi.

sosiashvili, g., (2018b). shida kartlshi osta samouravoebis sak'itkhisatvis, IV saertashoriso k'onperentsia „kartul-osur urtiertobata ganvitarebis p'ersp'ekt'ivebi", iv. javakhishvilis sakhelobis tbilisis sakhelmts'ipo universit'et'i, k'onperentsiis masalebi, tbilisi.

chibirovi, 1., (1990). samkhret osebis ist'oria, sasts'avlo sakhelmdzghvanelo, p'rop. 1. chibirovis red. tskhinvali.

tsot'niashvili, m., (1986). tskhinvalis ist'oria (tskhinvali peodalizmis khanashi), tbilisi.

javakhishvili, iv., (1901). khalkhis aghts'eris da shemosavlis davtrebi sakartveloshi, zhurnali ,moambe”, IV.

jikia, s., shengelia, n. (2009), 1728 ts'lis tbilisis vilaietis didi davtari, ts'igni I, osmaluri t'ekst'i kartuli targmanit, shesavlit, gamok'vlevita da paksimileebit gamosatsemad moamzades ak'ad. s. jikiam da p'rop. n. shengeliam, tbilisi.

Абаев, В., (1949). Осетинский язык и фольклор, I, Москва-Ленинград.

Ванеев, 3., (1936). К вопросу о времени заселения Юго-Осетии, „Известия Юго-Осетинского научно-иследовательского института , вып. III, Сталинир.

Волкова, Н. Г., (1974). Этнический состав населения Северного Кавказа в XVIII начале XX века, Москва.

Гамрекели, В., (1961). Двалы и Двалетия в I-XV вв., Тбилиси.

Зиссерман, К., (1870). Сборник материалов для описания Тифлисской губернии, под. ред. К. Зиссермана, т. I, вып. I, Тифлис.

Мачабели, С. В., (1887). Экономический быть государственных крестьянь Горийского уезда Тифлисской губернии, Тифлис.

Обозрения Российских владении за Кавказом, (1836). ч. II, отд. 7, Горийский уезд. Описание произведено Николаем Флоровским, Санкт-Петербург.

Пфаф, В. Б., (1870). Материалы для древней истории Осетии, „Сборник сведении о кавказских горцах", IV, Тифлис.

Свод статистических данных о населении Закавказского края извлечённых из посемейных списков 1886 г.Тифлисская губерния, Горийский уездь, (1893). \#1297-1305, 1394, Тифлись.

Труды Тифлисского губернского статистического комитета, (1886). вып. 1-й, сведения за 1884 и 1885 г.г. Тифлис.

Чхетия, Ш. К., (1954). Документы по истории Грузии (1862-1917), т. I, ч. I, под. ред. проф. Ш. К. Чхетия, Тбилиси. 